\title{
HAS2 wt Allele
}

National Cancer Institute

\section{Source}

National Cancer Institute. HAS2 wt Allele. NCI Thesaurus. Code C98003.

Human HAS2 wild-type allele is located in the vicinity of $8 q 24.12$ and is approximately 29

$\mathrm{kb}$ in length. This allele, which encodes hyaluronan synthase 2 protein, is involved in

glycosaminoglycan biosynthesis. A complex chromosomal rearrangement of

chromosome 8q fusing this gene and the PLAG1 gene is associated with lipoblastoma. 